\title{
Isolation and in vitro culture of primary cell populations derived from ovarian tissues of the rockfish, Sebastes schlegeli
}

\author{
Jun Hyung Ryu', Hak Jun Kim², Seung Seob Bae ${ }^{3}$, Choon Goo Jung ${ }^{3}$ and Seung Pyo Gong ${ }^{1,4^{*}}$
}

\begin{abstract}
This study was conducted to identify the general conditions for the isolation and in vitro culture of ovary-derived cells in rockfish (Sebastes schlegeli). The effects of three different enzymes on cell retrieval from ovarian tissues were evaluated first, and then the ovary-dissociated cells were cultured under various culture conditions, with varying basal media and culture temperatures, addition of growth factors, and/or culture types. We found that collagenase type I treatment was effective for cell isolation from ovarian tissues. From a total of 42 trials to evaluate the effects of basal media and culture temperatures on cell culture of ovary-dissociated cells, we observed that Leibovitz's L15 medium was more supportive than Dulbecco's modified Eagle's medium for culture, and the cells could grow at all three temperatures tested, 15,20 , and $25^{\circ} \mathrm{C}$, at least up to passage 2 . However, growth factor addition did not improve cell growth. Introduction of suspension culture after monolayer culture expanded the culture period significantly more than did monolayer culture alone. Our results may provide a basis for developing an in vitro system for S. schlegeli germline cell culture, which will ultimately lead to improvement of the species.
\end{abstract}

\section{Background}

Establishment of an in vitro system can provide a useful tool for biotechnology applications as well as various research areas (Lakra et al., 2011; Smagghe et al., 2009; Smith, 2006; Stacey, 2012). Particularly, in vitro utilization of germline cells that possess greater developmental potential can offer a novel way of deriving superior animals through grafting this in vitro system onto existing genetic breeding and transgenic technology (Gong et al., 2008; Shin et al., 2008; Kim et al., 2009; Kim and Izpisua Belmonte, 2011). In fish, however, a limited number of studies has been conducted to establish in vitro systems using germline cells, and most of those have been restricted to small fish models (Hong et al., 2004; Kawasaki et al., 2012; Nóbrega et al., 2010; Wong and Collodi, 2013; Wong et al., 2013). Thus, there has been little research regarding farmed fish species (Lacerda et al., 2010).

\footnotetext{
* Correspondence: gongsp@pknu.ac.kr

${ }^{1}$ Department of Fisheries Biology, Pukyong National University, Busan 608-737, Korea

${ }^{4}$ Laboratory of Cell Biotechnology, Department of Marine Biomaterials and Aquaculture, College of Fisheries Science, Pukyong National University, Busan 608-737, Korea

Full list of author information is available at the end of the article
}

Rockfish (Sebastes schlegeli) is a major farmed marine finfish, representing the second largest production of fish cultured in Korea (Jayasinghe et al., 2015). Thus, attempts to develop an in vitro system for culturing germline cells followed by improvement of the breed are important due to its commercial scale as a valuable food resource. In this study, as a first step towards the longterm goal of establishing a germline cell culture system in S. schlegeli, we first conducted primary cell cultures derived from S. schlegeli ovarian tissues to establish general guidelines for $S$. schlegeli cell culture by determining optimal culture conditions. We first compared the effects of three different enzymes on cell retrieval from ovarian tissues for efficient cell isolation and subsequently cultured the ovary-dissociated cells under various conditions to evaluate the effects of basal media, culture temperature, growth factors, and culture type on in vitro culture.

\section{Methods \\ Fish \\ Rockfish (S. schlegeli) were purchased from a local market from July to October. In total, 17 fish were used for this}


study, and the average weight and body length were 534.17 $\pm 64.46 \mathrm{~g}$ and $32.24 \pm 1.71 \mathrm{~cm}$, respectively. All procedures for animal management, euthanasia and surgery were complied with the guidelines of Institutional Animal Care and Use Committee (IACUC) of Pukyong National University and the ethical guidelines published by International Council for Laboratory Animal Science (ICLAS).

\section{Ovarian tissue collection and cell isolation}

To collect ovarian tissues, healthy female rockfish were sterilized using $70 \%$ ethanol (SK Chemicals, Sungnam, Korea) for $5 \mathrm{~min}$. The ovarian tissues were removed from the bodies using sterilized surgical equipment and washed five times in $\mathrm{Ca}^{2+} / \mathrm{Mg}^{2+}$-free Dulbecco's phosphate-buffered saline (DPBS; Gibco, Grand Island, NY, USA). To evaluate the effects of different enzymes on cell isolation, 200.14 $\pm 0.11 \mathrm{mg}$ ovarian tissue fragments were placed in $35-\mathrm{mm}$ Petri dishes (SPL life Sciences, Pocheon, Korea) filled with different digestive solutions: DPBS supplemented with $0.05 \%$ trypsin-EDTA (Gibco), $500 \mathrm{U} / \mathrm{mL}$ collagenase type I (Worthington Biochemical Corp., Lakewood Township, NJ, USA), and $500 \mathrm{U} / \mathrm{mL}$ collagenase type IV (Worthington Biochemical Corp.). Concentrations of each enzyme were determined on the basis of our previous study (Kim et al., 2014). Two collagenase solutions were prepared in $\mathrm{Ca}^{2+} / \mathrm{Mg}^{2+}$-containing DPBS, whereas the others were prepared in $\mathrm{Ca}^{2+} / \mathrm{Mg}^{2+}$-free DPBS. Then, the tissue fragments were chopped using a surgical blade and incubated for $30 \mathrm{~min}$ at $25{ }^{\circ} \mathrm{C}$ with periodic pipetting using wide-pore tips every $10 \mathrm{~min}$. After digestion, tissue derivatives were filtered through a $40-\mu \mathrm{m}$ cell strainer (BD Falcon, San Jose, CA, USA), and the cells were collected by centrifugation (400 $g$, $4 \mathrm{~min})$. The cells were then treated with red blood cell (RBC) lysis buffer $\left(155 \mathrm{mM} \mathrm{NH}_{4} \mathrm{Cl}, 10 \mathrm{mM} \mathrm{KHCO}_{3}\right.$, and $0.1 \mathrm{mM} \mathrm{Na} 2$.EDTA) for $5 \mathrm{~min}$ at $4{ }^{\circ} \mathrm{C}$ to remove $\mathrm{RBCs}$ and then collected by centrifugation $(400 \mathrm{~g}, 4 \mathrm{~min})$ after inactivation of the RBC lysis buffer by adding two volumes of $\mathrm{Ca}^{2+} / \mathrm{Mg}^{2+}$-free DPBS. Cell counting was conducted using a hemocytometer (Marienfeld, Lauda-Königshofen, Germany) after trypan blue (Gibco) staining. Cell viability was calculated as the number of live cells/number of total cells $\times 100$. For cell culture, the cells were isolated from whole ovaries under the same protocol as above, but RBS lysis buffer was not used due to its detrimental effects on cell culture.

\section{Culture media and supplements}

Two basal culture media, Leibovitz's L15 medium (L15; Gibco) and Dulbecco's modified Eagle's medium (DMEM; Gibco) containing $25 \mathrm{mM}$ HEPES, were used in this study. For cell culture, both media were supplemented with $20 \%$ (v/v) fetal bovine serum (Gibco) and a
$1 \%(\mathrm{v} / \mathrm{v})$ mixed solution of penicillin and streptomycin (Gibco). According to the treatment groups, $10 \mathrm{ng} / \mathrm{mL}$ basic fibroblast growth factor (bFGF; Gibco), $25 \mathrm{ng} / \mathrm{mL}$ epidermal growth factor (EGF; Sigma-Aldrich, St. Louis, MO, USA), 1000 units/mL leukemia inhibitory factor (LIF; Millipore, Billerica, MA, USA), 1 \% (v/v) fish serum from rainbow trout (FS; Caisson Laboratories, Smithfield, UT, USA), and/or $50 \mu \mathrm{g} / \mathrm{mL}$ medaka embryo extract (MEE) were added to the culture media. MEE was extracted as described previously (Lee et al., 2013).

\section{Cell culture}

The isolated cells were seeded in 12-well tissue culture plates (BD Falcon) coated with $0.1 \%$ gelatin (SigmaAldrich). A high cell density, $1.28 \pm 0.35$ (mean \pm standard deviation) $\times 10^{6}$ cells $/ \mathrm{cm}^{2}$, was used for each culture, and the cells were cultured at 15,20 , or $25{ }^{\circ} \mathrm{C}$ in air. On day 3 after the initial seeding, cells were washed twice with $\mathrm{Ca}^{2+} / \mathrm{Mg}^{2+}$-free DPBS, and the culture medium was refreshed. Thereafter, half of the medium was replaced every 2 or 3 days. When the cells reached 80-90 \% confluency, subculturing of the cells was conducted. The cells were washed twice with $\mathrm{Ca}^{2+} / \mathrm{Mg}^{2+}$-free DPBS and detached using $0.05 \%$ trypsin-EDTA. After collecting the cells by centrifugation $(400 \mathrm{~g}, 4 \mathrm{~min})$, they were suspended in culture medium and seeded on $0.1 \%$ gelatincoated tissue culture plates by splitting at a 1:2 ratio. For suspension culture, the collected cells were suspended in L15 and cultured on 35 or $60 \mathrm{~mm}$ Petri dishes (SPL life Sciences) at a density of $3.5 \times 10^{4}$ cells $/ \mathrm{cm}^{2}$. To exchange the medium in suspension cultures, cells and aggregates were collected by centrifugation $(400 \mathrm{~g}, 4 \mathrm{~min})$, and the aggregates were dissociated by treating with $0.05 \%$ trypsinEDTA for $3 \mathrm{~min}$. After collecting the cells by centrifugation ( $400 \mathrm{~g}, 4 \mathrm{~min}$ ), the cells were suspended in L15 and cultured on 35 or $60 \mathrm{~mm}$ Petri dishes. Medium exchange was conducted every 6 or 7 days. Primary cell attachment and cell morphology were examined visually under an inverted microscope (TS100-F, Nikon, Tokyo, Japan).

\section{Statistical analysis}

The SAS (SAS Institute, Cary, NC, USA) software was used to analyze the effect of each treatment. If a significant main effect was detected by analysis of variance, treatments were analyzed subsequently by the least squares method or Duncan's method. Differences among treatments were considered significant at a $P$ value $<0.05$.

\section{Results \& discussion}

Effects of different enzyme solutions on cell isolation

To develop an effective cell isolation method, we evaluated the effects of three different enzymes on cell retrieval and viability in the isolation procedure. As shown in Fig. 1, high levels of cell retrieval were achieved in the 


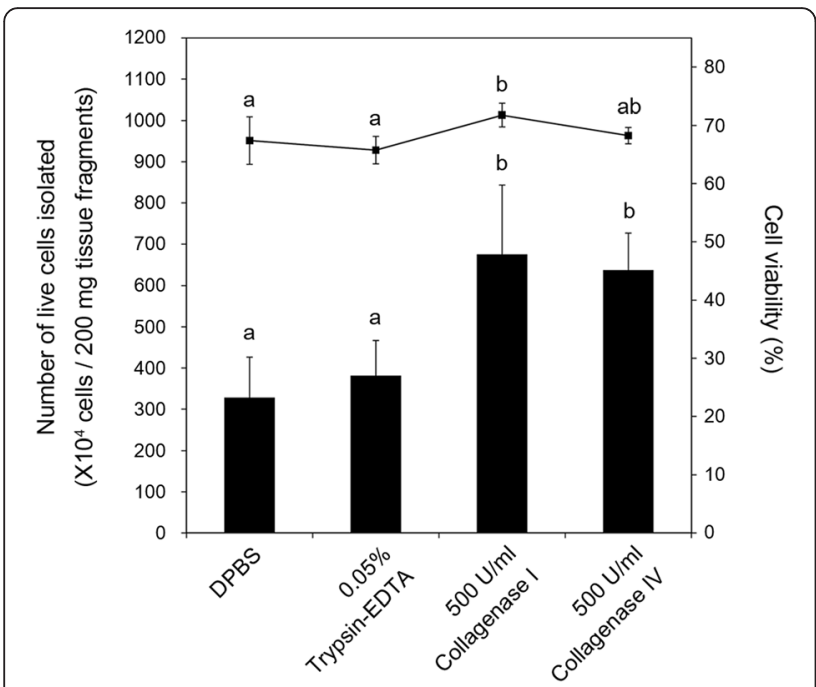

Fig. 1 Effects of different enzyme solutions on retrieving the cells from ovarian tissues of Sebastes schlegeli. Ovarian tissues retrieved were chopped by surgical blade in four different solutions and the number of cells isolated and cell viability were measured. Significant high cell retrieval was detected in collagenase type I and IV solutions and highest cell viability was achieved in collagenase type I solution. All data are mean \pm standard deviation of four independent experiments. ${ }^{\mathrm{ab}}$ Different letters indicate significant differences $(p<0.05)$

two groups treated with collagenase type I and collagenase type IV. The mean \pm standard deviation numbers of live cells isolated from $200 \mathrm{mg}$ tissue fragments were $328 \pm 98 \times 10^{4}, 381 \pm 86 \times 10^{4}, 675 \pm 168 \times 10^{4}$, and 637 $\pm 90 \times 10^{4}$ in DPBS, $0.05 \%$ trypsin-EDTA, $500 \mathrm{U} / \mathrm{mL}$ collagenase type I, and $500 \mathrm{U} / \mathrm{mL}$ collagenase type IV, respectively, from four independent experiments $(p=$ $0.0019)$. In terms of cell viability, the cells isolated by collagenase type I treatment showed the highest value: 71.8 $\pm 2.0 \%(p=0.0450)$. Overall, we found that $500 \mathrm{U} / \mathrm{mL}$ collagenase type I treatment was an effective way to retrieve live cells from $S$. schlegeli ovarian tissues.
Cell isolation by tissue dissociation is a major step in cell culture, and many factors can affect tissue dissociation procedures. Of these factors, the choice of enzyme is critical to maximize the viable cell yield, and it can usually be determined by the type of tissue subjected to dissociation, because different tissues have different extracellular matrix compositions. However, due to the variability in the extracellular matrix according to the physiological status of the animal species and type of tissue, enzyme selection needs to be conducted empirically. Trypsin is a commonly used enzyme in tissue disaggregation, because it is effective on many cells and tissues. Similarly, the use of crude collagenase preparations has been found suitable for many mammalian cell cultures because of their effectiveness at breaking intercellular tissue matrices via collagenolytic and proteolytic activities (Freshney, 2010). Among the crude collagenase preparations evaluated, collagenase type I, which contains the original balance among collagenase, caseinase, clostripain, and tryptic activities (Can and Karahuseyinoglu, 2007), is widely used for the dissociation of many different kinds of tissues, including ovarian tissues in several mammalian species, such as the mouse (Gong et al., 2010), rat (Ando et al., 1999), and rabbit (Setrakian et al., 1993). Similar results were derived from our study, demonstrating suitability for S. schlegeli ovarian tissues as well. This provides fundamental information for cell culture of S. schlegeli, as well as other fish species, for which tissue dissociation procedures have not been well established. Nevertheless, additional conditions, such as the temperature, incubation time, and enzyme concentration for enzymatic dissociation, remain to be optimized in each case.

\section{Effects of media and temperature on the culture of ovary- dissociated cells}

To determine the optimal culture conditions for S. schlegeli ovary-dissociated cells, we first investigated the effects of basal medium and culture temperature on primary cell attachment and continuous culture. Two different basal

Table 1 Culture outcome of Sebastes schlegeli ovary-dissociated cells according to temperature and basal media

\begin{tabular}{|c|c|c|c|c|c|c|c|}
\hline \multirow{2}{*}{$\begin{array}{l}\text { Temperature } \\
\left({ }^{\circ} \mathrm{C}\right)\end{array}$} & \multirow{2}{*}{$\begin{array}{l}\text { Basal } \\
\text { media }^{a}\end{array}$} & \multirow{2}{*}{$\begin{array}{l}\text { No. of cell } \\
\text { populations } \\
\text { tested }\end{array}$} & \multirow{2}{*}{$\begin{array}{l}\text { No. }(\%)^{b} \text { of cell } \\
\text { populations initially attached }\end{array}$} & \multicolumn{4}{|c|}{ No. $(\%)^{b}$ of cell populations subcultured to } \\
\hline & & & & Passage 1 & Passage 2 & Passage 3 & Passage 4 \\
\hline \multirow[t]{2}{*}{15} & L15 & 7 & $7(100)$ & $7(100)$ & $3(43)$ & $1(14)$ & $0(0)$ \\
\hline & DMEM & 7 & $7(100)$ & $3(43)$ & $1(14)$ & $0(0)$ & $0(0)$ \\
\hline \multirow[t]{2}{*}{20} & L15 & 7 & $7(100)$ & $6(86)$ & $3(43)$ & $1(14)$ & $0(0)$ \\
\hline & DMEM & 7 & $7(100)$ & $3(43)$ & $0(0)$ & $0(0)$ & $0(0)$ \\
\hline \multirow[t]{3}{*}{25} & L15 & 7 & $7(100)$ & $5(71)$ & $2(29)$ & $1(14)$ & $1(14)$ \\
\hline & DMEM & 7 & $7(100)$ & $3(43)$ & $0(0)$ & $0(0)$ & $0(0)$ \\
\hline & Total & 42 & $42(100)$ & $27(64)$ & $9(21)$ & $3(7)$ & $1(2)$ \\
\hline
\end{tabular}

${ }^{a}$ For cell culture, basal media were supplemented with $20 \%(\mathrm{v} / \mathrm{v})$ fetal bovine serum and $1 \%(\mathrm{v} / \mathrm{v})$ mixed solution of penicillin and streptomycin

${ }^{b}$ Percentage of the number of cell populations tested 
Table 2 Effects of temperature and basal media on the culture of Sebastes schlegeli ovary-dissociated cells

\begin{tabular}{|c|c|c|c|c|c|c|c|}
\hline \multirow[t]{2}{*}{ Factors } & \multirow[t]{2}{*}{ Group } & \multirow{2}{*}{$\begin{array}{l}\text { No. of cell } \\
\text { populations } \\
\text { tested }\end{array}$} & \multirow{2}{*}{$\begin{array}{l}\text { No. }(\%)^{a} \text { of cell } \\
\text { populations initially attached }\end{array}$} & \multicolumn{4}{|c|}{ No. (\%) ${ }^{a}$ of cell populations subcultured to } \\
\hline & & & & Passage 1 & Passage 2 & Passage 3 & Passage 4 \\
\hline Whole replicates & Merged & 42 & $42(100)$ & $27(64)$ & $9(21)$ & $3(7)$ & $1(2)$ \\
\hline \multirow[t]{3}{*}{ Basal media } & L15 & 21 & $21(100)$ & $18(86)$ & $8(38)$ & $3(14)$ & $1(5)$ \\
\hline & DMEM & 21 & $21(100)$ & $9(43)$ & $1(5)$ & $0(0)$ & $0(0)$ \\
\hline & $P$-value & & - & 0.003 & 0.0076 & 0.0754 & 0.3233 \\
\hline Temperature & 15 & 14 & $14(100)$ & $10(71)$ & $4(29)$ & $1(7)$ & $0(0)$ \\
\hline \multirow[t]{3}{*}{$\left({ }^{\circ} \mathrm{C}\right)$} & 20 & 14 & $14(100)$ & $9(64)$ & $3(21)$ & $1(7)$ & $0(0)$ \\
\hline & 25 & 14 & $14(100)$ & $8(57)$ & $2(14)$ & $1(7)$ & $1(7)$ \\
\hline & $P$-value & & - & 0.7475 & 0.6717 & 1.0000 & 0.3771 \\
\hline
\end{tabular}

This table was derived from reallocation of data from Table 1

apercentage of the number of cell populations tested

media, L15 and DMEM, were assessed in cell culture under three different temperatures of 15,20 , and $25^{\circ} \mathrm{C}$. As shown in Table 1, all 42 cell populations cultured showed primary cell attachment regardless of the experimental treatments. Of the cell populations, $64 \%(27 / 42)$, $21 \%(9 / 42), 7 \%(3 / 42)$, and $2 \%(1 / 42)$ grew and survived beyond the first, second, third, and fourth subcultures, respectively, but no cell population reached the fifth subculture. We found that L15 as a basal medium was better than DMEM for cell culture (Table 2). A higher number of cell populations grew to passage 2 when cultured in L15 than in DMEM ( $86 \%$ vs. $43 \%$ to passage $1, p=0.03$, and $38 \%$ vs. $5 \%$ to passage $2, p=0.0076$ ). However, no significant treatment effect on the initial cell culture was detected at the different culture temperatures, suggesting that the cultured cells can grow in the temperature range of 15 to $25^{\circ} \mathrm{C}$, at least up to passage 2. Significant differences in cell growth were observed between the cells cultured in L15 and DMEM. On the basis of many previous studies that reported successful fish cell culture in an air atmosphere (Abdul Majeed et al., 2013; Kim et al., 2014; Lee et al., 2015), we used an air atmosphere instead of $\mathrm{CO}_{2}$ gas to culture $S$. schlegeli ovary-dissociated cells. L15 medium was originally designed for use in culture without $\mathrm{CO}_{2}$, and DMEM was supplemented with HEPES to control the physiological pH (Will et al., 2011). Less support for DMEM for cell growth might be a result of phototoxicity caused by the production of hydrogen peroxide from light-exposed HEPES (Lepe-Zuniga et al., 1987; Zigler et al., 1985). More evidence may be derived from additional experiments using appropriate reactive oxygen species scavengers.

As an important factor controlling the physicochemical culture properties, the optimal culture temperature is largely dependent on the body temperature of the animal from which the cells were

Table 3 Effects of various growth factors on the culture of Sebastes schlegeli ovary-dissociated cells

\begin{tabular}{|c|c|c|c|c|}
\hline \multirow{2}{*}{$\begin{array}{l}\text { Composition } \\
\text { of culture } \\
\text { medium }\end{array}$} & \multirow{2}{*}{$\begin{array}{l}\text { No. of cell } \\
\text { populations } \\
\text { tested }\end{array}$} & \multirow{2}{*}{$\begin{array}{l}\text { No. }(\%)^{a} \text { of cell populations } \\
\text { initially attached }\end{array}$} & \multicolumn{2}{|c|}{ No. $(\%)^{a}$ of cell populations subcultured to } \\
\hline & & & Passage 1 & Passage 2 \\
\hline B & 6 & $6(100)$ & $6(100)$ & $2(33)$ \\
\hline$B+E$ & 3 & $3(100)$ & $3(100)$ & $1(33)$ \\
\hline$B+F$ & 3 & $3(100)$ & $3(100)$ & $1(33)$ \\
\hline$B+L$ & 3 & $3(100)$ & $3(100)$ & $1(33)$ \\
\hline$B+E+F$ & 3 & $3(100)$ & $3(100)$ & $1(33)$ \\
\hline$B+E+L$ & 3 & $3(100)$ & $3(100)$ & $1(33)$ \\
\hline$B+F+L$ & 3 & $3(100)$ & $3(100)$ & $1(33)$ \\
\hline$B+E+F+L$ & 3 & $3(100)$ & $3(100)$ & $1(33)$ \\
\hline$B+F S$ & 3 & $3(100)$ & $3(100)$ & $2(67)$ \\
\hline$B+M E E$ & 3 & $3(100)$ & $3(100)$ & $2(67)$ \\
\hline$B+F S+M E E$ & 3 & $3(100)$ & $3(100)$ & $2(67)$ \\
\hline
\end{tabular}

B, L15 medium containing $20 \%$ fetal bovine serum and $1 \%$ mixed solution of penicillin and streptomycin; $\mathrm{E}, 25 \mathrm{ng} / \mathrm{ml}$ epidermal growth factor; $\mathrm{F}$, $10 \mathrm{ng} / \mathrm{ml}$ basic fibroblast growth factor; L, 1000 units/ml leukemia inhibitory factor; FS, $1 \%$ fish serum; MEE, $50 \mu \mathrm{g} / \mathrm{ml}$ medaka embryo extract

${ }^{\text {a }}$ Percentage of the number of cell populations tested 
derived (Freshney, 2010). In the case of S. schlegeli, a wide range of temperatures was tested, because as a poikilotherm, it can tolerate a wide temperature range (Md Mizanur et al., 2014). Because all of the temperatures tested supported the growth of $S$. schlegeli ovary-dissociated cells to passage 2 , we decided to fix the culture temperature for further study at $15{ }^{\circ} \mathrm{C}$ due to the tolerance of cultured cells to low relative to higher temperatures (Freshney, 2010). Further examinations targeting stable continuous cell lines may be required to determine the optimal culture temperature.

There may be several reasons why cell growth was limited to passage 1 or 2 in most cases. It may be the original senescence timing of S. schlegeli ovary-dissociated cells, or it may be caused by a lack of appropriate signaling molecules stimulating cell growth. Next, we evaluated the effects of various growth factors, including EGF, bFGF, LIF, $\mathrm{FS}$, and MEE, on cell growth in L15 medium and $15{ }^{\circ} \mathrm{C}$ culture temperature. We confirmed again that ovarydissociated cells can grow and survive at least to passage 1 when cultured under these conditions regardless of added growth factors but observed that none of the growth factors tested induced further growth of the cultured cells (Table 3). These results may indicate that the limitation in cell growth was due to the senescence of cultured cells at passage 1 or 2 , although additional signaling molecules that originate from S. schlegeli or allied species need to be tested.

\section{Effects of culture types on in vitro maintenance of ovary- dissociated cells}

Throughout the culture of S. schlegeli ovary-dissociated cells, we observed that all cultured cell populations formed primarily a monolayer in culture (Fig. 2a), but they detached spontaneously from the substratum as the culture progressed, resulting in the removal of a
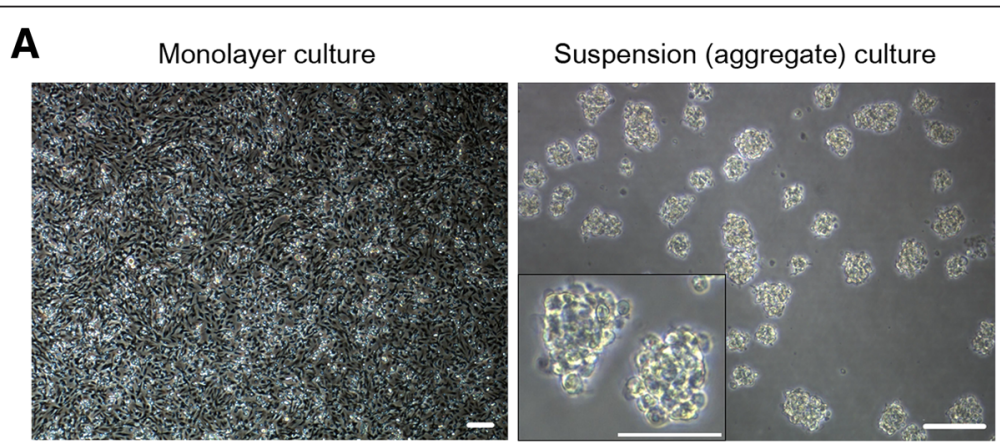

B

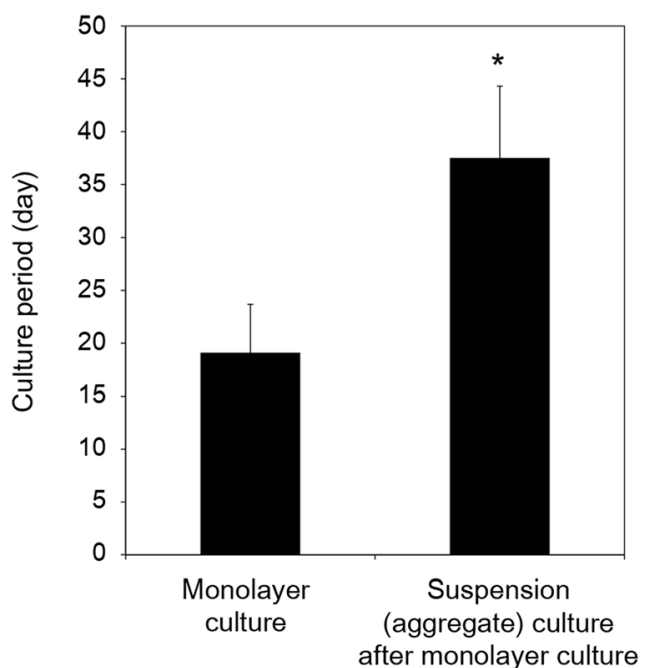

Fig. 2 Effects of culture type on culturing Sebastes schlegeli ovary-dissociated cells. Four cell populations derived from monolayer culture were detached on substratum at first or second passage and subsequently cultured as a form of aggregates in suspension manner for each individual. Culture period was measured individually on all cell populations cultured. a Morphology of the cells and cell aggregates in monolayer and suspension culture, respectively. Box within the picture of suspension culture shows a magnified image of aggregates. Scale bar $=100 \mu \mathrm{m}$ and $50 \mu \mathrm{m}$ in pictures and box, respectively. $\mathbf{b}$ Comparison of culture period between monolayer culture and suspension (aggregate) culture after monolayer culture. Combination of monolayer and suspension culture induced a statistically significant long-term maintenance of the cell populations compared with the sole monolayer culture. The data are mean \pm standard deviation of nine and four independent experiments in monolayer and suspension culture, respectively. Asterisk indicates significant difference, $p<0.05$ 
large proportion of the cells during media exchange. Eventually, it brought about a shortening of the culture period in vitro. To increase the culture period of the cells, we attempted a suspension culture after a monolayer culture and compared the total culture period between suspension culture after monolayer culture and monolayer culture alone. Four cell populations in the monolayer culture derived from different individuals were detached artificially from the substratum using $0.05 \%$ trypsin-EDTA treatment at the first or second passage and subsequently cultured in a suspension manner individually. The cells in suspension culture formed cell aggregates spontaneously (Fig. 2a), which were maintained without significant morphological changes. A significant increase in culture period was detected in suspension culture after monolayer culture versus monolayer culture alone (Fig. 2b; $37.5 \pm 6.8$ vs. $19.1 \pm 4.6$ days, $p<0.0001)$. Short-term primary cultures have limited application because of a lack of reproducibility and cell homogeneity. Thus, long-term culture or development of continuous cell lines is required for certain biotechnological applications of cultured cells (Bols et al., 1994). Consequently, extension of the culture period by introducing suspension culture is important in that it provides more time to add additional treatments for establishing long-term cultivable cells, such as spontaneous induction of cell immortalization and artificial induction of cell transformation. Additionally, aggregate formation in suspension culture has potential advantages, such as ease of cell maintenance, culture at high cell densities (Kyung et al., 1992), and provision of a threedimensional microenvironment (Welter et al., 2007). These suggest the potential for further development of this culture system. Additional studies to activate cell proliferation followed by establishment of continuous cell lines are needed.

\section{Conclusions}

We report the general conditions for in vitro culture of $S$. schlegeli ovary-dissociated cells. Tissue dissociation and cell isolation can be implemented effectively using collagenase type I, and the cells can be cultured in L15 medium under a range of temperatures. Additionally, a combination of monolayer and suspension culture can extend the culture period significantly. The results of this study provide a basis for establishing an in vitro system for $S$. schlegeli germline cell culture.

\section{Competing interests}

The authors declare that they have no competing interests.

\section{Authors' contributions}

JHR carried out the experiments. SSB, CGJ, and HJK participated in experimental design and data analysis. SPG conceived and designed the study, analyzed the data, and wrote manuscript. All authors read and approved the final manuscript.

\section{Acknowledgments}

This research was supported by National Marine Biodiversity Institute Research Program (2015 M00700) and Basic Science Research Program through the National Research Foundation of Korea (NRF) funded by the Ministry of Education (NRF-2015R1D1A1A01059056).

\section{Author details}

'Department of Fisheries Biology, Pukyong National University, Busan 608-737, Korea. ${ }^{2}$ Department of Chemistry, Pukyong National University, Busan 608-737, Korea. ${ }^{3}$ Marine Biodiversity Institute of Korea, Seochun 33662, Korea. ${ }^{4}$ Laboratory of Cell Biotechnology, Department of Marine Biomaterials and Aquaculture, College of Fisheries Science, Pukyong National University, Busan 608-737, Korea.

Received: 18 March 2016 Accepted: 1 April 2016

Published online: 12 April 2016

\section{References}

Abdul Majeed S, Nambi KS, Taju G, Sundar Raj N, Madan N, Sahul Hameed AS. Establishment and characterization of permanent cell line from gill tissue of Labeo rohita (Hamilton) and its application in gene expression and toxicology. Cell Biol Toxicol. 2013;29:59-73.

Ando M, Kol S, Irahara M, Sirois J, Adashi EY. Non-steroidal anti-inflammatory drugs (NSAIDs) block the late, prostanoid-dependent/ceramide-independent component of ovarian IL-1 action: implications for the ovulatory process. Mol Cell Endocrinol. 1999;157:21-30.

Bols NC, Barlian A, Chirina-Trejo M, Caldwell SJ, Goegan P, Lee LEJ. Development of a cell line from primary cultures of rainbow trout, Oncorhynchus mykiss (Walbaum), gills. J Fish Dis. 1994;17:601-11.

Can A, Karahuseyinoglu S. Concise review: human umbilical cord stroma with regard to the source of fetus-derived stem cells. Stem Cells. 2007;25:2886-95.

Freshney RI. Culture of Animal Cells: A Manual of Basic Technique and Specialized Applications. 6th ed. Hoboken: Wiley-Blackwell; 2010.

Gong SP, Lee EJ, Lee ST, Kim H, Lee SH, Han HJ, et al. Improved establishment of autologous stem cells derived from preantral follicle culture and oocyte parthenogenesis. Stem Cells Dev. 2008;17:695-712.

Gong SP, Lee ST, Lee EJ, Kim DY, Lee G, Chi SG, et al. Embryonic stem cell-like cells established by culture of adult ovarian cells in mice. Fertil Steril. 2010;93: 2594-601.

Hong Y, Liu T, Zhao H, Xu H, Wang W, Liu R, et al. Establishment of a normal medakafish spermatogonial cell line capable of sperm production in vitro. Proc Natl Acad Sci U S A. 2004;101:8011-6.

Jayasinghe JD, Elvitigala DA, Whang I, Nam BH, Lee J. Molecular characterization of two immunity-related acute-phase proteins: haptoglobin and serum amyloid a from black rockfish (Sebastes schlegeli). Fish Shellfish Immunol. 2015;45:680-8.

Kawasaki T, Saito K, Sakai C, Shinya M, Sakai N. Production of zebrafish offspring from cultured spermatogonial stem cells. Genes Cells. 2012;17:316-25.

Kim IW, Gong SP, Yoo CR, Choi JH, Kim DY, Lim JM. Derivation of developmentally competent oocytes by the culture of preantral follicles retrieved from adult ovaries: maturation, blastocyst formation, and embryonic stem cell transformation. Fertil Steril. 2009;92:1716-24.

Kim MS, Nam YK, Park C, Kim HW, Ahn J, Lim JM, et al. Establishment condition and characterization of heart-derived cell culture in Siberian sturgeon (Acipenser baerii). In Vitro Cell Dev Biol Anim. 2014;50:909-17.

Kim S, Izpisua Belmonte JC. Pluripotency of male germline stem cells. Mol Cells. 2011;32:113-21.

Kyung YS, Peshwa MV, Perusich CM, Hu WS. Dynamics of Aggregate Culture of Mammalian Cells. In: Animal Cell Technology: Basic \& Applied Aspects. Netherlands: Springer; 1992. p. 65-9.

Lacerda SM, Batlouni SR, Costa GM, Segatelli TM, Quirino BR, Queiroz BM, et al. A new and fast technique to generate offspring after germ cells transplantation in adult fish: the Nile tilapia (Oreochromis niloticus) model. PLOS ONE. 2010:5:e10740.

Lakra WS, Swaminathan TR, Joy KP. Development, characterization, conservation and storage of fish cell lines: a review. Fish Physiol Biochem. 2011;37:1-20.

Lee D, Kim MS, Nam YK, Kim DS, Gong SP. Establishment and characterization of permanent cell lines from Oryzias dancena embryos. Fish Aquat Sci. 2013;16: $177-85$.

Lee D, Ryu JH, Lee ST, Nam YK, Kim DS, Gong SP. Identification of embryonic stem cell activities in an embryonic cell line derived from marine medaka (Oryzias dancena). Fish Physiol Biochem. 2015;41:1569-76. 
Lepe-Zuniga JL, Zigler Jr JS, Gery I. Toxicity of light-exposed Hepes media. J Immunol Methods. 1987;103:145.

Md Mizanur R, Yun H, Moniruzzaman M, Ferreira F, Kim KW, Bai SC. Effects of feeding rate and water temperature on growth and body composition of juvenile Korean rockfish, Sebastes schlegeli (Hilgendorf 1880). Asian-Australas J Anim Sci. 2014;27:690-9.

Nóbrega RH, Greebe CD, van de Kant H, Bogerd J, de França LR, Schulz RW. Spermatogonial stem cell niche and spermatogonial stem cell transplantation in zebrafish. PLOS ONE. 2010;5:e12808.

Setrakian S, Oliveros-Saunders B, Nicosia SV. Growth stimulation of ovarian and extraovarian mesothelial cells by corpus luteum extract. In Vitro Cell Dev Biol Anim. 1993;29A:879-83.

Smith CL. Mammalian cell culture. Curr Protoc Mol Biol. 2006;28:1-28.0.2.

Smagghe G, Goodman CL, Stanley D. Insect cell culture and applications to research and pest management. In Vitro Cell Dev Biol Anim. 2009:45:93-105.

Stacey G. Current developments in cell culture technology. Adv Exp Med Biol. 2012;745:1-13.

Shin SS, Kim TM, Kim SY, Kim TW, Seo HW, Lee SK, et al. Generation of transgenic quail through germ cell-mediated germline transmission. FASEB J. 2008;22: 2435-44.

Welter JF, Solchaga LA, Penick KJ. Simplification of aggregate culture of human mesenchymal stem cells as a chondrogenic screening assay. Biotechniques. 2007;42:732-7.

Will MA, Clark NA, Swain JE. Biological pH buffers in IVF: help or hindrance to success. J Assist Reprod Genet. 2011;28:711-24.

Wong $\Pi$ T, Collodi P. Dorsomorphin promotes survival and germline competence of zebrafish spermatogonial stem cells in culture. PLoS ONE. 2013;8, e71332.

Wong TT, Tesfamichael A, Collodi P. Production of zebrafish offspring from cultured female germline stem cells. PLoS ONE. 2013;8:e62660.

Zigler Jr JS, Lepe-Zuniga JL, Vistica B, Gery I. Analysis of the cytotoxic effects of light-exposed HEPES-containing culture medium. In Vitro Cell Dev Biol. 1985; 21:282-7.

\section{Submit your next manuscript to BioMed Central and we will help you at every step:}

- We accept pre-submission inquiries

- Our selector tool helps you to find the most relevant journal

- We provide round the clock customer support

- Convenient online submission

- Thorough peer review

- Inclusion in PubMed and all major indexing services

- Maximum visibility for your research

Submit your manuscript at www.biomedcentral.com/submit

) Biomed Central 